\title{
An efficient overexpression method for studying genes in Ricinus that transport vectorized agrochemicals
}

\author{
Yongxin Xiao ${ }^{1 \dagger}$, Jinying Zhang ${ }^{1 \dagger}$, Yiting $\mathrm{Li}^{1}$, Tom Hsiang ${ }^{2}$, Xingping Zhang ${ }^{1}$, Yongxing Zhu ${ }^{1}$, Xiaoying Du', \\ Junliang Yin ${ }^{1^{*}}$ (D) and Junkai Li ${ }^{1^{*}}$
}

\begin{abstract}
Background: Plant plasma membrane transporters play essential roles during the translocation of vectorized agrochemicals. Therefore, transporters associated with phloem loading of vectorized agrochemicals have drawn increasing attention. As a model system, castor bean (Ricinus communis L.) has been widely used to detect the phloem mobility of agrochemicals. However, there is still a lack of an efficient protocol for the Ricinus seedling model system that can be directly used to investigate the recognition and phloem loading functions of plasmalemma transporters toward vectorized agrochemicals.
\end{abstract}

Results: Here, using vacuum infiltration strategy, we overexpressed the coding gene for enhanced green fluorescent protein (eGFP) in R. communis seedlings by Agrobacterium tumefaciens-mediated transformation system. Strong fluorescence signals were observed in leaves, demonstrating that exogenous genes can be successfully overexpressed in seedlings. Subsequently, gene expression time and vacuum infiltration parameters were optimized. Observation of fluorescence and qRT-PCR analysis showed that eGFP strength and expression level reached a peak at $72 \mathrm{~h}$ after overexpression in seedlings. Parameter optimization showed Agrobacterium concentration at $\mathrm{OD}_{600}=1.2$, and infiltration for $20 \mathrm{~min}(0.09 \mathrm{MPa})$, return to atmospheric pressure, and then infiltration for another $20 \mathrm{~min}$, were the suitable transformation conditions. To test the application of vacuum agroinfiltration in directly examining the loading functions of plasma membrane transporters to vectorized agrochemicals in seedlings, two LHT (lysine/histidine transporter) genes, RCLHT1 and RCLHT7, were overexpressed. Subcellular localization showed the strong fluorescent signals of the fusion proteins RcLHT1-eGFP and RCLHT7-eGFP were observed on the cell membrane of mesophyll cells, and their relative expression levels determined by qRT-PCR were up-regulated 47- and 52-fold, respectively. Furthermore, the concentrations of L-Val-PCA (L-valine-phenazine-1-carboxylic acid conjugate) in phloem sap collected from seedling sieve tubes were significantly increased 1.9- and 2.3-fold after overexpression of RCLHT1 and RCLHT7, respectively, implying their roles in recognition and phloem loading of L-Val-PCA.

\footnotetext{
*Correspondence: yinjunliang@yangtzeu.edu.cn; junkaili@sina.com

${ }^{\dagger}$ Yongxin Xiao and Jinying Zhang contributed equally to this work

${ }^{1}$ Hubei Key Laboratory of Waterlogging Disaster and Agricultural Use of Wetland/Institute of Pesticides/College of Agriculture/College of Life Science/College of Horticulture and Gardening, Yangtze University, Jingzhou 434025, Hubei, China

Full list of author information is available at the end of the article
} permits use, sharing, adaptation, distribution and reproduction in any medium or format, as long as you give appropriate credit to the original author(s) and the source, provide a link to the Creative Commons licence, and indicate if changes were made. The images or other third party material in this article are included in the article's Creative Commons licence, unless indicated otherwise in a credit line to the material. If material is not included in the article's Creative Commons licence and your intended use is not permitted by statutory regulation or exceeds the permitted use, you will need to obtain permission directly from the copyright holder. To view a copy of this licence, visit http://creativecommons.org/licenses/by/4.0/. The Creative Commons Public Domain Dedication waiver (http://creativeco mmons.org/publicdomain/zero/1.0/) applies to the data made available in this article, unless otherwise stated in a credit line to the data. 
Conclusions: We successfully constructed a transient expression system in Ricinus seedlings and laid the foundation for researchers to directly investigate the loading functions of plasma membrane transporters to vectorized agrochemicals in the Ricinus system.

Keywords: L-Val-PCA (L-valine-phenazine-1-carboxylic acid conjugate), Vacuum infiltration, Subcellular localization, Plasma-membrane transporter, Recognizing and phloem loading

\section{Background}

Vectorized agrochemicals are capable of increased systemic activity over the parent pesticides and thus, improve the efficacy of pesticides against insect pests and fungal pathogens, and allow for decreasing rates or usage and hence reduction of threats to the environment [1]. Some non-phloem-mobile parental compounds can be modified to be vectorized agrochemicals and acquire phloem translocation by conjugation with nutrients such as sugars or amino acids, after which the plasma membrane transporters will recognize those nutrients moieties and load the conjugated compounds into sieve tubes for transport in the phloem. Consequently, rational utilization of the plant membrane transporters has become a critical point for the design and syntheses of vectorized agrochemicals [2-4]. For example, the insecticidal fipronil derivatives [5], rotenone derivatives [6], and chlorantraniliprole derivatives [7] acquired phloem mobility by conjugation of active ingredients with specific amino acids. PCA, a natural product isolated from the metabolites of the phytopathogens Pseudomonas sp. M18, has been found to be effective against numerous soilborne fungal pathogens and registered as biofungicide against rice sheath blight in China [8]. Recently, a derivative PCA has achieved phloem translocation by conjugation of its carboxyl group with amino groups of $\mathrm{L}$ type amino acids $[9,10]$. Among PCA derivatives, L-Val-PCA (L-valinephenazine-1-carboxylic acid) exhibited the highest phloem mobility [9]. Since valine is a neutral amino acid and LHTs (lysine and histidine transporters) are classified as higher affinity transporters for neutral and acidic amino acids $[11,12]$, we speculated that LHTs could be potentially involved in the recognition and loading of L-Val-PCA.

Deciphering the recognition and loading functions of transporters toward vectorized agrochemicals can facilitate the rational utilization of these plasma-membrane carriers in modification strategies for non-phloemmobile parental compounds. Previously, several systems have been used to investigated the recognition and loading functions of transporters toward vectorized agrochemicals. For example, Xenopus laevis oocyte was used to study the function of plant monosaccharide transporter RcSTP1 and reveal its affinity for a glucose-fipronil conjugate (GTF) [13]. Arabidopsis thaliana was used to detect the uptake ability of roots for an alanine-chlorantraniliprole conjugate after overexpressing AtAAP1 [14]. Although above systems were suitable for gene heterologous expression, they are not designed to specifically survey the phloem mobility of vectorized agrochemicals. The Xenopus laevis oocyte system can be used to demonstrate the active transport of xenobiotics, but it can't be used to specifically examine phloem mobility because the Xenopus laevis oocyte is animal cell, which does not have a vascular bundle. The Arabidopsis thaliana was limited by the difficulty of qualitative and quantitative manipulation, incubation of the leaf veins because of the cuticle, and the storage compounds in the leaf "buffered" most of the experimental treatments. Therefore, Arabidopsis exhibits few "phloem bleeding" upon incision of the bark [15]. The Ricinus seedling has been frequently used as a model plant system to qualitatively and quantitatively detect the phloem mobility of various agrochemicals, which has advantages in the analysis of sieve-tube sap with mature incubation method and thus possesses the property of investigating the response of the phloem loading system to pesticides in the leaf. Because the cotyledons of seedling without a cuticle, it can readily respond to incubation with solutes. Furthermore, Ricinus is one of the industrially important oilseed crops. Wilt disease caused by Fusarium oxysporum f. sp. ricini is an important oil and seed borne disease in castor and results in significant yield losses [16]. Thus, studies of phloem mobility of vectorized agrochemicals contribute to the control of castor wilt disease by foliar spraying. However, there is still a lack of an efficient method in seedlings that can be directly used to investigate the functions of plasma membrane transporters for recognition and phloem mobility of vectorized agrochemicals.

The Agrobacterium tumefaciens-mediated transformation system (ATMTs) is widely used for exogenous gene function analysis in plant. For example, ATMTs has been used to introduce a miraculin gene into callus of carrot (Daucus carota L.), and during cell division, the miraculin gene was highly expressed in transgenic callus lines [17]. In addition, ATMTs was also used to transfect the sections of young cotyledon in tomato (Solanum lycopersicum L.) to examine overexpression of target genes [18]. Furthermore, vacuum infiltration, widely described to enhance Agrobacterium infection, has been successfully 
used to produce transgenic plants in wheat [19], Arabidopsis [20], cotton [21], bean [22], banana [23], coffee [24], citrus [25], and watermelon [26]. This vacuum agroinfiltration protocol improves the transformation efficiency by enhancing the penetration of Agrobacterium into target tissues [27].

The transformation efficiency of an exogenous gene with transient expression was influenced by multiple parameters when mediated by vacuum agroinfiltration. For instance, Amoah et al. [28] found that increasing the Agrobacterium cell density, the duration of inoculation, and the vacuum pressure were able to enhance the expression of uidA when transforming inflorescent tissue in immature wheat. Accordingly, in the current study, parameters to be tested included the gene expression time for surveying fluorescence signal after infiltration, Agrobacterium cell density, and vacuum infiltration time, to optimize them for transformation to create an overexpression protocol for seedlings. After transformation RcLHT1 and RcLHT7, the phloem mobility of vectorized agrochemical L-Val-PCA was assessed by HPLC.

\section{Materials and methods Plant materials}

To develop a gene transient expression protocol for seedlings, seeds purchased from the Zibo Academy of Agricultural Science were sown into vermiculite following Rocher et al. [29]. Six days later, uniformly growing seedlings, with stem widths of $3.0 \pm 0.2 \mathrm{~cm}$, were selected, and the endosperm (20 mm length) was carefully removed for further experiments.

\section{Construction of vacuum agroinfiltration in Ricinus seedlings}

To demonstrate that exogenous genes can be transiently expressed in seedlings, the eGFP gene was selected because it can acquire transient overexpression with the cauliflower mosaic virus (CaMV) $35 \mathrm{~S}$ promoter [30]. The plant binary expression vector pART27-eGFP (College of Agriculture, Yangtze University) was transformed into Agrobacterium tumefaciens strain GV3101 by the freezemelt method [31]. Then, GV3101 carrying pART27-eGFP was cultured for $20 \mathrm{~h}$ in $400 \mathrm{~mL} \mathrm{LB}$ medium containing $50 \mu \mathrm{g} / \mathrm{mL}$ spectinomycin and $20 \mu \mathrm{g} / \mathrm{mL}$ rifampim. After centrifugation (Avanti JXN-30, Beckman Coulter, California, USA) at $8000 \mathrm{~g}$ for $5 \mathrm{~min}$, the collected Agrobacterium cells were resuspended in $200 \mathrm{~mL}$ buffer solution containing $10 \mathrm{mM}$ MES (pH 5.6), $10 \mathrm{mM} \mathrm{MgCl}_{2}$ and $200 \mu \mathrm{M}$ acetosyringone, to reach an $\mathrm{OD}_{600}$ of Agrobacterium cells of 1.0 [32].

Then endosperm-excised seedlings were soaked in the Agrobacterium suspension and subjected to vacuum infiltration (JX820D-1, SMAF, Shanghai, China) at $0.09 \mathrm{MPa}$ for $20 \mathrm{~min}$. When infiltration was complete, seedlings were transferred into Hogland solution and cultured in a cold-light source incubator (GDX-330, Safu, Ningbo, China) for $72 \mathrm{~h}$ at $18{ }^{\circ} \mathrm{C}$ in the dark [33]. Then the seedlings were observed under UV light (UVP BLAK-RAY B-100AP LAMP, Analytic Jena, Jena, Germany) to confirm eGFP expression.

\section{Optimization of overexpression time of exogenous gene}

The eGFP signal was monitored at $100 \times$ magnification by laser confocal microscopy (TCS-SP8, Leica, Wetzlar, Germany) at $24 \mathrm{~h}, 48 \mathrm{~h}, 72 \mathrm{~h}$, and $96 \mathrm{~h}$, and then photographed. Because the wild type seedlings did not express $e G F P$, the relative expression level of $e G F P$ after incubation for $2 \mathrm{~h}$ in wild type seedlings was used as the baseline control. For each treatment, cotyledons of at least three seedlings were harvested, quickly frozen in liquid nitrogen, and stored at $-80{ }^{\circ} \mathrm{C}$ for RNA isolation. The total RNA from Ricinus cotyledons was extracted using Total RNA Extraction Reagent (Vazyme, Nanjing, China) following a reported method [34]. The quality of RNA was measured with an UV-Vis spectrophotometer (Q6000M, Quawell, San Jose, USA).

For qRT-PCR analysis, the HiScript ${ }^{\circledR}$ II First Strand cDNA Synthesis Kit (Vazyme, Nanjing, China) was used to synthesize the first-strand cDNA using $1 \mu \mathrm{g}$ total RNA. Each $20 \mu \mathrm{L}$ reaction contained $10 \mu \mathrm{L} 2 \times \mathrm{RT}$ Mix, $4 \mu \mathrm{L}$ HiScript II Enzyme Mix, $1 \mu \mathrm{L}$ oligo $(\mathrm{dT})_{23} \mathrm{VN}(50 \mu \mathrm{M})$, $1 \mu \mathrm{L}$ random hexamers $(50 \mathrm{ng} / \mu \mathrm{L})$, and nuclease-free $\mathrm{H}_{2} \mathrm{O}$ up to $20 \mu \mathrm{L}$. The reverse transcription program was $25^{\circ} \mathrm{C}$ for $5 \mathrm{~min}, 50^{\circ} \mathrm{C}$ for $15 \mathrm{~min}$, and $85^{\circ} \mathrm{C}$ for $2 \mathrm{~min}$.

The qPCR was performed in a CFX Connect ${ }^{\mathrm{TM}}$ RealTime PCR detection system (Bio-Rad, California, USA). Each $20 \mu \mathrm{L}$ reaction contained $10 \mu \mathrm{L} 2 \times$ ChamQ Universal SYBR qPCR Master Mix (Vazyme, Nanjing, China), $0.4 \mu \mathrm{L}$ forward/reverse primers $(10 \mu \mathrm{M}), 1 \mu \mathrm{L}$ cDNA, and nuclease-free $\mathrm{H}_{2} \mathrm{O}$ up to $20 \mu \mathrm{L}$. The $R$. communis Actin gene was used as the reference [13]. The relative expression levels of $e G F P$ were calculated by the $2^{-\Delta \Delta C t}$ method [35]. Significant treatment effects were assessed with ANOVA followed by mean separation using Dunnett's test in SPSS software. Forward/Reverse primers of $e G F P$ gene were designed using Primer Premier 5.0 software (Premier Biosoft International, Computing Associates, Palo Alto, USA) [36].

\section{Optimization of vacuum infiltration parameters}

The parameters of vacuum infiltration were optimized by surveying eGFP signal strength. A series of Agrobacterium cell densities was used to infiltrate seedlings, and $\mathrm{OD}_{600}$ values at $0.4,0.8,1.2$, and 1.6 were used. Different infiltration times were also tested, including $10 \mathrm{~min}$, $20 \mathrm{~min}, 20$ plus $20 \mathrm{~min}$, and $40 \mathrm{~min}$. The 20 plus $20 \mathrm{~min}$ 
treatment referred to vacuum infiltration for $20 \mathrm{~min}$, then return to atmospheric pressure (about $2 \mathrm{~min}$ ), and then infiltration for another $20 \mathrm{~min}$. After $72 \mathrm{~h}$, eGFP signal strength was observed at $100 \times$ magnification by laser confocal microscopy, and relative expression rate of eGFP was assessed by counting the cells with and without eGFP signal [37].

\section{Subcellular localization}

To determine the expression and localization of the two transporters, RcLHT1 and RcLHT7, recombinants pART27-RcLHT1-eGFP and pART27-RcLHT7eGFP were constructed as follows. CDS of RcLHT1 and RcLHT7 were downloaded from the NCBI database. Then two primers for full-length amplification of RcLHT1 and RcLHT7 were designed using Primer Premier 5.0 software. The $5^{\prime}$ end of the forward primer contained an Xho I site and 15 bp homologous sequences, which were located upstream of the Xho I site of pART27-eGFP. The $5^{\prime}$ end of the reverse primer also contained an Xho I site and $15 \mathrm{bp}$ homologous sequences downstream. Phanta ${ }^{\circledR}$ Max Super-Fidelity DNA Polymerase (Vazyme, Nanjing, China) was used for full-length amplification of RcLHT1 and RcLHT7 by PCR. Moreover, the empty vector pART27-eGFP was digested with Xho I for plasmid linear. Then PCR products and linear pART27-eGFP were separated and purified by $1 \%$ agarose gel electrophoresis. Subsequently, ClonExpress ${ }^{\circledR}$ II One Step Cloning Kit (Vazyme, Nanjing, China) was used to connect target fragments to pART27-eGFP by the In-Fusion method [38]. Plant binary expression vector pCAMBIA1300-35S-PM-mCherry (MiaolingBio, Wuhan, China) was used as plasma membrane marker. Furthermore, marker and two constructed recombinant plasmids were transformed into $A$. tumefaciens strain GV3101 by the freeze-melt method. The transformant carrying two recombinant vectors was cultured for $18 \mathrm{~h}$ in $5 \mathrm{~mL} \mathrm{LB}$ medium containing $50 \mu \mathrm{g} / \mathrm{mL}$ spectinomycin and $20 \mu \mathrm{g} / \mathrm{mL}$ rifampin. But the difference was that the transformant carrying marker was cultured in LB medium containing $50 \mu \mathrm{g} / \mathrm{mL}$ kanamycin. After centrifugation at $5000 \mathrm{~g}$ for $5 \mathrm{~min}$, the collected Agrobacterium cells were resuspended in MES solution containing $200 \mu \mathrm{M}$ acetosyringone, to reach an $\mathrm{OD}_{600}$ of Agrobacterium cells of 0.4 . The resuspension carrying marker was mixed with the resuspension carrying two recombinants in $50 \mathrm{~mL}$ centrifuge tubes following the ratio of $1: 1$, respectively. Mixtures were placed at room temperature for $2 \mathrm{~h}$, and then transformed into 6-leave stage Nicotiana benthamiana by stab inoculation. After culture for $72 \mathrm{~h}$ at $23 \pm 1{ }^{\circ} \mathrm{C}$, fluorescence signals were observed at $400 \times$ magnification by laser confocal microscopy.

\section{Phloem sap collection and analysis}

To demonstrate the role of the two transporters in phloem loading of L-Val-PCA, the transformant carrying recombinants pART27-RcLHT1-eGFP and pART27RcLHT7-eGFP were cultured for $18 \mathrm{~h}$ in $400 \mathrm{~mL} \mathrm{LB}$ medium containing $50 \mu \mathrm{g} / \mathrm{mL}$ spectinomycin and $20 \mu \mathrm{g} /$ $\mathrm{mL}$ rifampin. After centrifugation and resuspension, the transformant was introduced into seedlings by vacuum agroinfiltration $(0.09 \mathrm{MPa}$, OD $600=1.2$, 20 plus $20 \mathrm{~min})$. After culturing at $18{ }^{\circ} \mathrm{C}$ in dark for $72 \mathrm{~h}$, fluorescence signal strength in seedlings was surveyed under UV light. The seedlings that introduced pART27-eGFP were used as controls.

Cotyledons cultured at $18{ }^{\circ} \mathrm{C}$ in darkness were harvested, quickly frozen in liquid nitrogen and stored at $-80{ }^{\circ} \mathrm{C}$ for RNA isolation. The total RNA was extracted and the first-strand cDNA was synthesized as above. Two primers for qRT-PCR of RcLHT1 and RcLHT7 were designed using Primer Premier 5.0 software. Then the relative expression levels of RcLHT1 and RcLHT7 were detected after incubation for $72 \mathrm{~h}$. The relative expression levels at $0 \mathrm{~h}$ were used as controls.

The phloem sap collection method was similar to that described by Rocher et al. [29]. The samples were analyzed by HPLC (Haineng LC7000, Jinan, China) after phloem sap was diluted with UHQ-grade water $(1+9$ $\mathrm{v} / \mathrm{v})$ and purified through a sterile filter $(\mathrm{r}=0.22 \mu \mathrm{m})$. The target L-Val-PCA was separated with a C18 reversedphase column (length $150 \mathrm{~mm}$, inner diameter $4.6 \mathrm{~mm}$, $5 \mu \mathrm{m})$. The mobile phase consisted of methanol and water containing $0.1 \%$ phosphoric acid at a flow rate of $0.8 \mathrm{~mL} / \mathrm{min}$, and the injection volume was $10 \mu \mathrm{L}$. Various standard solutions $(0.4,0.8,1,2$, and $5 \mathrm{mg} / \mathrm{L})$ of test compounds for calibration curves were prepared in methanol. Results were processed with Wookinglab software v00.02.20.00 (Haineng, Jinan, China). The data were subjected to ANOVA followed by mean separation using Dunnett's test in SPSS software.

\section{Results and discussion \\ Exogenous gene was expressed in Ricinus communis seedling}

The fluorescence signals were surveyed $72 \mathrm{~h}$ after pART27-eGFP was transformed into Ricinus seedlings. eGFP signals were observed in most seedling leave under UV light, but signal strength varied. Strong signals were commonly observed alongside the veins and weak signal were at the leaf margin (Fig. 1I). This may be due to the stomates were the main channel for vacuum infiltration of Agrobacterium into leaves and less stomates were found at the margin area of Ricinus leaves [39], and thus less Agrobacterium was accumulated at 

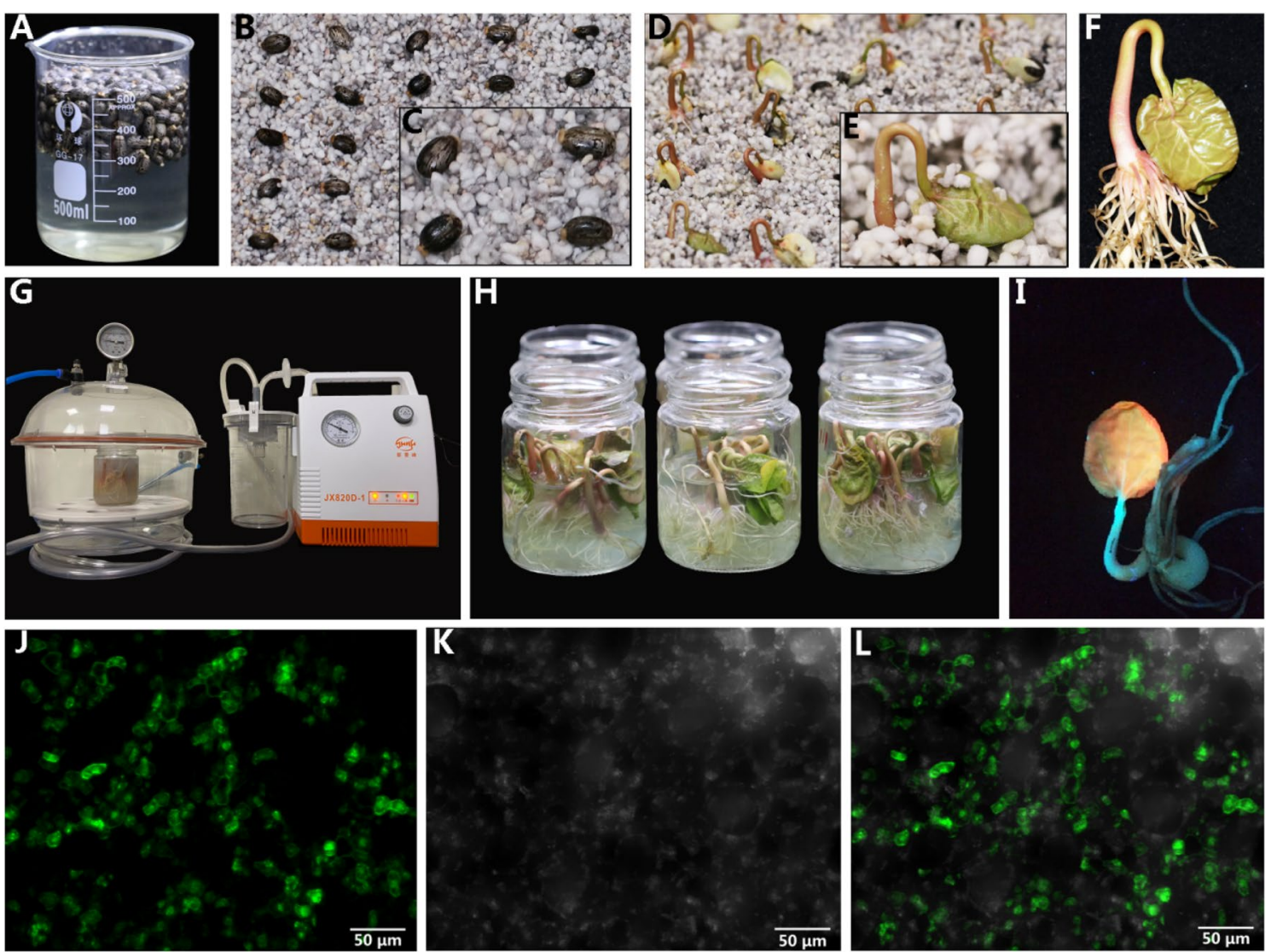

Fig. 1 Construction of vacuum agroinfiltration in Ricinus communis seedling. A Castor bean seeds were immersed in water in $500 \mathrm{~mL}$ beaker for $24 \mathrm{~h}$ at $27 \pm 1^{\circ} \mathrm{C}$. B, C Seeds were sowed in wet vermiculite. D, E Seeds were cultured while maintaining humidity for 6 days. F Seedlings with stems $3.0 \pm 0.2 \mathrm{~cm}$ across, were selected and endosperm (20 mm length) carefully removed. G Endosperm-excised seedlings were placed in Agrobacterium suspension in $250 \mathrm{~mL}$ bottles of plant tissue culture. Vacuum infiltration was at $0.09 \mathrm{MPa}$ for $20 \mathrm{~min}$. $\mathbf{H}$ Seedlings were soaked in Hogland solution and cultured at $18^{\circ} \mathrm{C}$ in dark for $72 \mathrm{~h}$. I eGFP were observed under UV light. J-L The eGFP signal observed at 100x magnification by laser confocal microscopy under fluorescence, bright, and merged fields

leaf margin. Under UV light, seedlings with strong fluorescence signals can be easily selected and used in subsequent experiments. eGFP signals were checked by laser confocal microscopy and strong fluorescence signals were observed in mesophyll cells (Fig. 1J). The outline of mesophyll cells were also observed under bright light (Fig. 1K) and overlay effect under fluorescence and bright fields were showed in Fig. 1L. Overall, as showed in Fig. 1, using the vacuum agroinfiltration strategy, an exogenous gene was successfully expressed in seedlings. Vacuum infiltration has allowed for high-efficiency introduce of the Agrobacterium binary vector into exposed plant tissues and high-level expression for target proteins [40], especially for the plants with hard or succulent leaves [41]. In this study, seedlings were transferred into Hogland solution after infiltration, and cultured for $72 \mathrm{~h}$ at $18{ }^{\circ} \mathrm{C}$ in the dark [33]. This low temperature prevented fast growth and disappearance of the hook region, which is approx. $1.0 \mathrm{~cm}$ apart from the cotyledons as show in
Fig. 1F, I and convenient for the incubation of cotyledons, because these transformed seedlings need to be used for further collection of phloem sap. However, the effects of lower temperatures on eGFP expression need further investigation.

\section{Optimization of transient expression parameters}

The change of fluorescence strength and eGFP gene expression level after infiltration were surveyed. Results showed that eGFP signal could be observed at $24 \mathrm{~h}$, though the signal was weak; and then the fluorescence signal increased and reached peak level at $72 \mathrm{~h}$, decreasing by $96 \mathrm{~h}$ (Fig. 2A1-A4). Consistently, the qRT-PCR analysis also confirmed that eGFP was continuously up-regulated from 24 to $72 \mathrm{~h}$. The maximum expressed level appeared at $72 \mathrm{~h}$, which was about 76-fold comparing to control (Fig. 2B). Previous studies showed that the highest level of target gene expression could be generally 

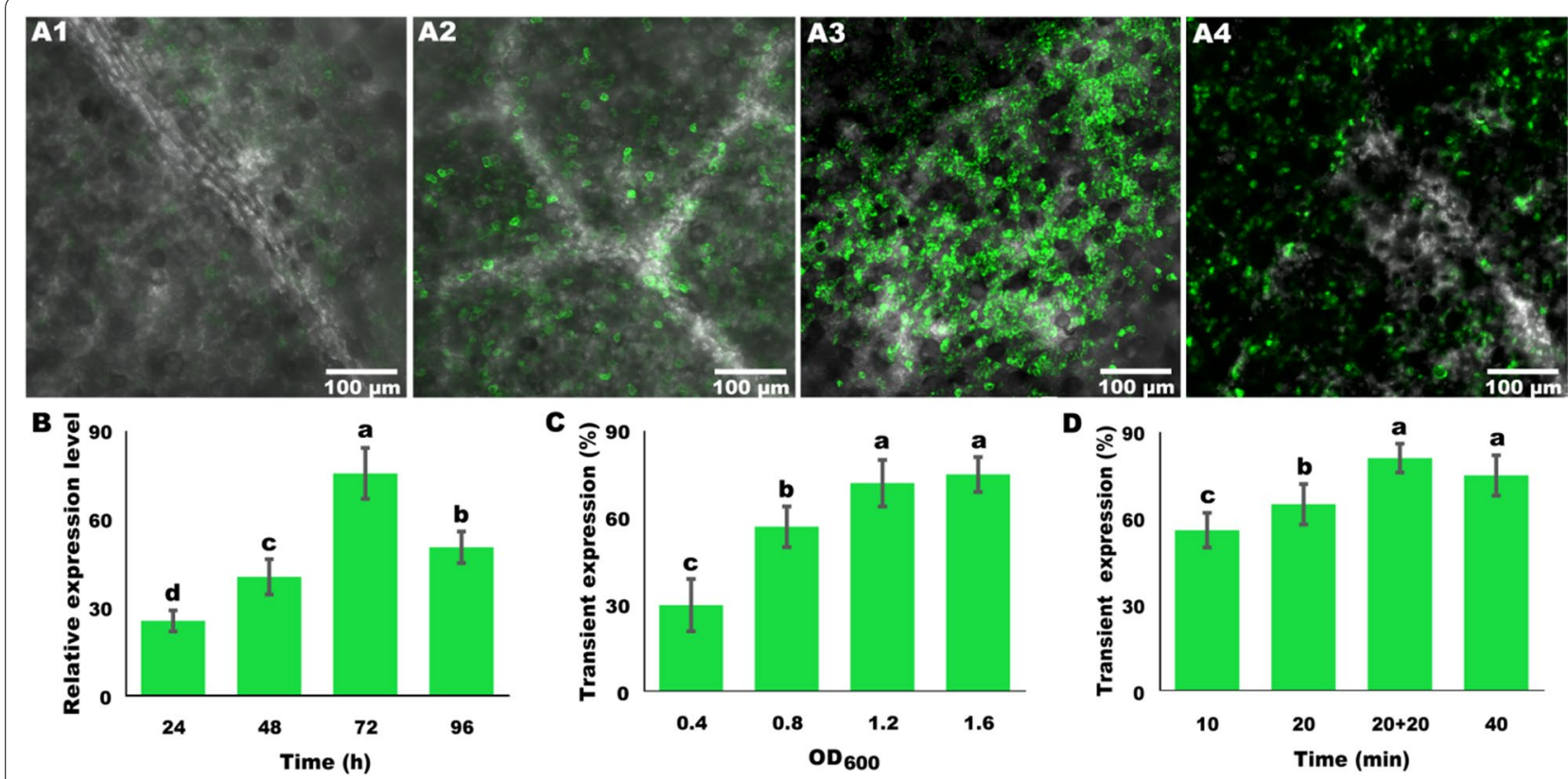

Fig. 2 Optimization of overexpression parameters. A1-A4 Observation of fluorescence strength by laser confocal microscopy in merged field at $24 \mathrm{~h}, 48 \mathrm{~h}, 72 \mathrm{~h}$, and $96 \mathrm{~h}$. B Relative expression level of eGFP after $24 \mathrm{~h}, 48 \mathrm{~h}, 72 \mathrm{~h}$, and $96 \mathrm{~h}$, detected respectively. C Optimization of Agrobacterium concentration. Series Agrobacterium cell densities, including $\mathrm{OD}_{600}$ at $0.4,0.8,1.2$, and 1.6, were used. D Optimization of infiltration time. The duration of vacuum infiltration was set at $10 \mathrm{~min}, 20 \mathrm{~min}, 20$ plus $20 \mathrm{~min}$ and $40 \mathrm{~min}$. All data were collected and handled from three biological replicates. Different samples were used during these biological replicates. Letters on the graphs denote statistically significant differences (ANOVA, $P<0.05)$

observed 2-3 days post infiltration, after which the expression level typically decreases [40, 42-44].

Besides, the optimization results of Agrobacterium cell density with $\mathrm{OD}_{600}$ from 0.4 to 1.6 , showed that eGFP signal strength continuously increased, and the highests level of eGFP expression was between $\mathrm{OD}_{600}$ 1.2 and 1.6 which were not significantly different (Fig. 2C). Consistent with our results, Amoah et al. [28] also found that increasing the Agrobacterium cell density could enhance the expression of exogenous gene, which reached a peak at $\mathrm{OD}_{600}=1.5$, whereas they also chose $\mathrm{OD}_{600}=1.2$ as the optimal cell density for vacuum infiltration.

The duration of vacuum was optimized. Four patterns, including $10 \mathrm{~min}, 20 \mathrm{~min}, 40 \mathrm{~min}$, and 20 plus $20 \mathrm{~min}$, were tested in this study. The results showed that, with the increasing of filtration time from 10 to $40 \mathrm{~min}$, fluorescence strength was continuously increased. When the infiltration time was set at 20 plus 20 min, fluorescence signal strength was found to be the strongest (Fig. 2D). Previous study showed that 20 min was needed to obtain a complete infiltration with the Agrobacterium suspension in adult $A$. thaliana transformation [45]. Furthermore, the vacuum extracts gases from submerged plant leaves through stomata and, when the vacuum is released and pressure rapidly increases, the suspension of Agrobacterium is driven to leaves to replace the extracted gases [46]. Therefore, the strategy of vacuum infiltration for a period, return to atmospheric pressure, then vacuum infiltration again has been commonly used [47].

\section{Subcellular localization of RcLHT1 and RcLHT7}

Two constructed vectors pART27-RcLHT1-eGFP and pART27-RcLHT7-eGFP with marker were co-transformed into Nicotiana benthamiana. After culture for $72 \mathrm{~h}$, we found that the fluorescent signals of fusion proteins RcLHT1-eGFP and RcLHT7-eGFP were located in the plasma membrane of mesophyll cells (Fig. 3A1, B1). Meanwhile, as shown in Fig. 3A2, B2, the Discosoma red fluorescent protein (DsRed) signals of marker were also observed in the plasmalemma. Although cell shape was unclear under bright field because of the thick cuticles (Fig. 3A3, B3), we still demonstrated that two transporters, RcLHT1 and RcLHT7, are actually located in the plasma membrane under merged field (Fig. 3A4, B4). That further confirmed that RcLHT1 and RcLHT7 function as transporters and participate in membrane translocation of amino acids [48]. However, no fluorescent signals of fusion proteins RcLHT1-eGFP and RcLHT7eGFP were found in the plasma membrane of epidermic cells. 

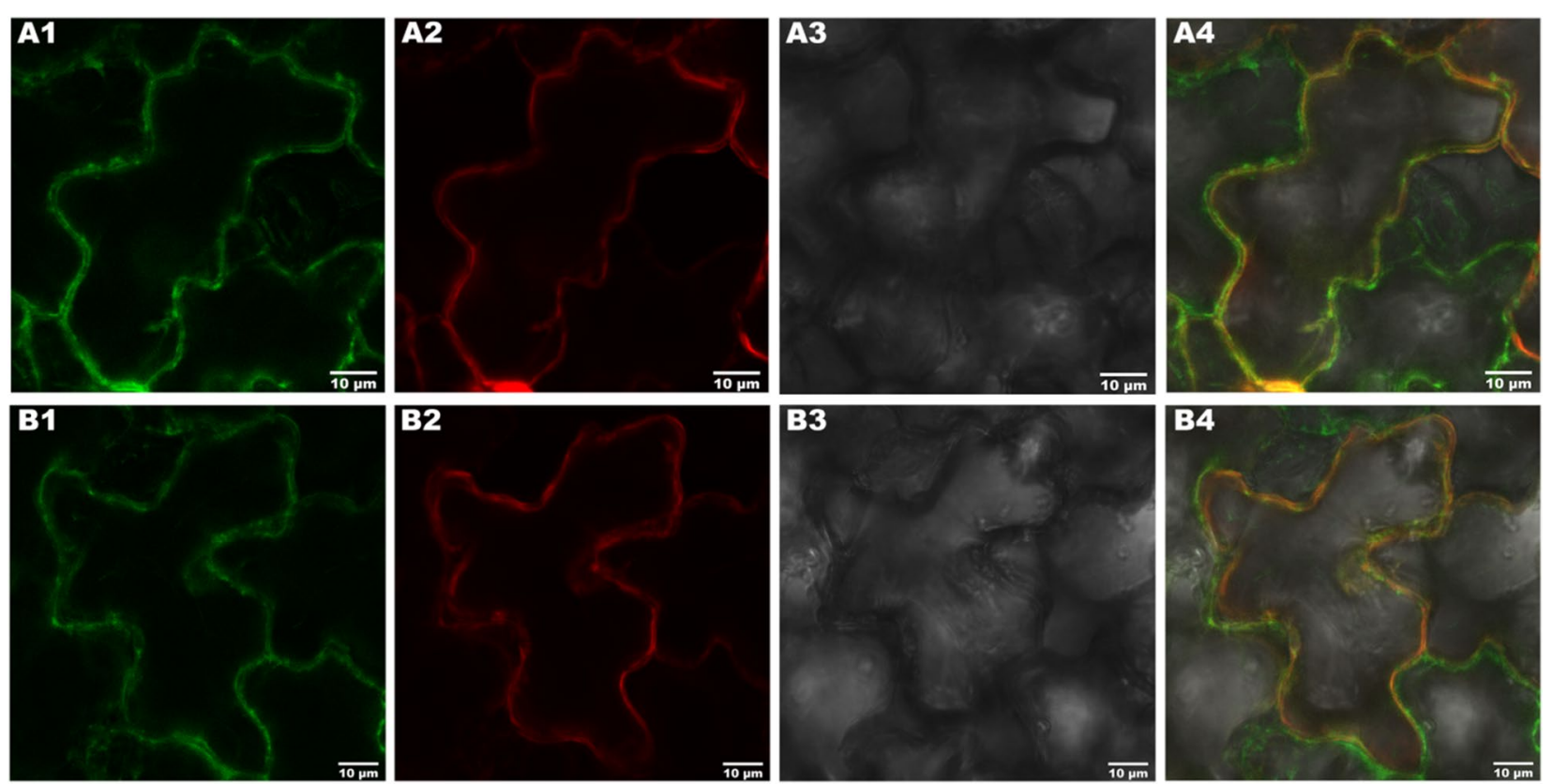

Fig. 3 Expression and localization observation of RcLHT1 A and RcLHT7 B in mesophyll cells of Nicotiana benthamiana by laser confocal microscopy, A1, B1 under green fluorescence A2, B2 red fluorescence, A3, B3 bright, A4, B4 and merged fields

\section{Overexpression of RCLHT1 and RcLHT7 significantly improved the phloem mobility of L-Val-PCA}

Two vectors pART27-RcLHT1-eGFP and pART27RcLHT7-eGFP were transformed into seedlings. After incubation for $72 \mathrm{~h}$, fluorescent signals of fusion proteins RcLHT1-eGFP and RcLHT7-eGFP were surveyed. As showed in Fig. 4A1, B1, similar to eGFP, strong fluorescence signal was observed alongside the Ricinus cotyledon veins instead of leaf margins under UV light. Meanwhile, qRT-PCR showed that the relative expression level of RcLHT1 significantly higher than control for 43-fold (Fig. 4A2), and RcLHT7 higher for 52-fold (Fig. 4B2). The above results indicated RcLHT1 and RcLHT7 acquired successful transient expressed in seedlings.

Then the loading function of RcLHT1 and RcLHT7 toward L-Val-PCA was surveyed. The standard curve $(y=0.11747 x+2.33291)$ was built and used for HPLC determination. The correlation coefficient was 0.998 . The results of HPLC revealed that the concentration of $\mathrm{L}-\mathrm{Val}-$ PCA in phloem sap was $37.85 \mu \mathrm{M}$ after overexpression of $R c L H T 1$, and the control without overexpression was $19.79 \mu \mathrm{M}$. The phloem loading efficiency was improved almost twofold (Fig. 4A3). As for RcLHT7, the concentration of L-Val-PCA was $36.82 \mu \mathrm{M}$, and the control without overexpression was $16.04 \mu \mathrm{M}$. The phloem mobility was improved 2.3-fold (Fig. 4B3). These results indicated that overexpression of RcLHT1 and RcLHT7 significantly improved the phloem mobility of L-Val-PCA in seedlings, which indicating their roles in recognition and phloem loading of this vectorized agrochemical. Jiang et al. [49] similarly found that AtLHT1, an Arabidopsis gene homolog to RcLHT1 and RcLHT7, participated in the uptake process of an L-glutamine-fipronil conjugate (L-GlnF), and overexpression of AtLHT1 led to $83 \%$ increase in the uptake of $\mathrm{L}-\mathrm{GlnF}$.

Recently, several assays have been used to survey the transporting functions of plasma-membrane carriers to vectorized agrochemicals. For example, Xenopus laevis oocytes were used to decipher the affinity of plant monosaccharide transporter, RcSTP1, to a glucose-fipronil conjugate (GTF) [13]; and Arabidopsis thaliana was used to study the function of AtAAP1 in promoting the rates by roots of the alanine-chlorantraniliprole conjugate [14]. Compared to above systems, the Ricinus seedling system can be directly used to investigate the recognition and phloem loading functions of transporters of vectorized agrochemicals, which will aid in strategic rational utilization of these plasma-membrane carriers.

\section{Conclusion}

In this study, we successfully developed a protocol for Agrobacterium tumefaciens-mediated transformation of Ricinus seedling and optimized the parameters. The optimum time for detection of overexpression of exogenous gene was $72 \mathrm{~h}$. The Agrobacterium cell density 

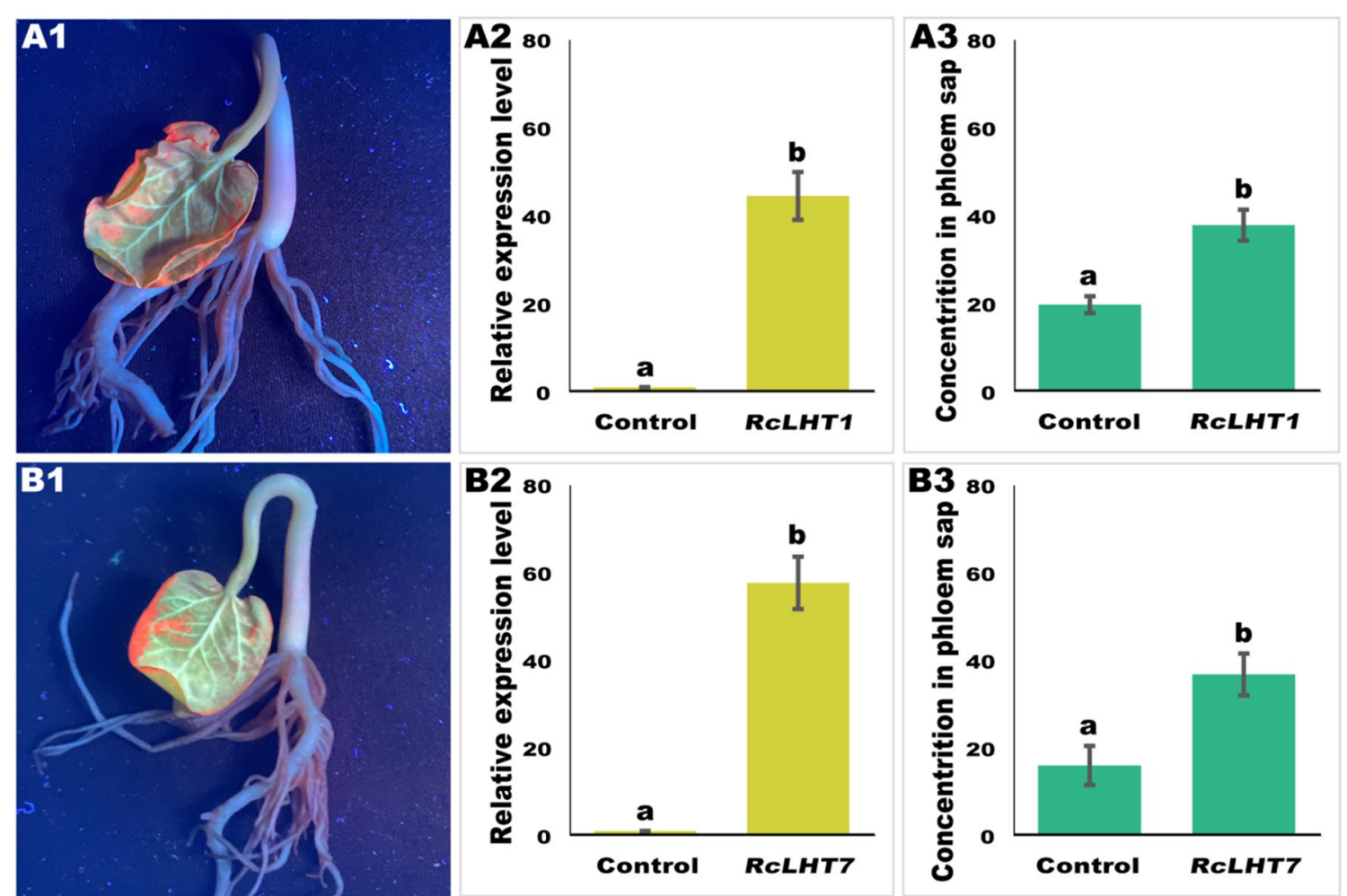

Fig. 4 Overexpression of RCLHT1 and RCLHT7 improved the phloem mobility of L-Val-PCA. A1, B1 UV light survey, A2, B2 qRT-PCR analysis, and A3, B3 measurement of L-Val-PCA concentration in phloem sap collection after overexpression of RCLHT1 and RCLHT7 for $72 \mathrm{~h}$ in Ricinus seedlings. Overexpression of EGFP was used as a check when measuring L-Val-PCA concentration in phloem sap collection. Each test contains three biological replicates. Different samples were used during these biological replicates. Letters on the graphs denote statistically significant differences (ANOVA, $P<0.05)$

was $\mathrm{OD}_{600}=1.2$, and the infiltration time was 20 plus 20 min (vacuum infiltration for $20 \mathrm{~min}$, then return to atmospheric pressure, and then infiltration for another $20 \mathrm{~min}$ ). Using this method, overexpression of RcLHT1 and RcLHT7 can significantly increase the phloem translocation of L-Val-PCA in sieve tubes of seedlings, suggesting that RcLHT1 and RcLHT7 participate in the recognition and phloem loading of L-Val-PCA. Our results provide a foundation for researchers to directly investigate the loading functions of plasma-membrane transporters toward vectorized agrochemicals in Ricinus seedling system.

\section{Acknowledgements}

We are grateful to Professor Yiqing Liu of Yangtze University for providing the qPCR hardware in this article.

\section{Authors' contributions}

$J L Y$ and JKL designed the study. YXX, JYZ and YTL performed the experiments. $Y X X, J Y Z$ and $X P Z$ analyzed the data. JLY, JKL, TH, and XYD supervised the study. YXX, YXZ and JLY wrote this paper. All authors read and approved the final manuscript.

\section{Funding}

This work was supported by the National Key R\&D Program of China (2018YFD0200500) and the National Science Foundation of China (31672069).

\section{Availability of data and materials}

All data and material generated or analysed during this study are included in this published article.

\section{Declarations}

Ethics approval and consent to participate

Not applicable.

\section{Consent for publication}

Not applicable.

\section{Competing interests}

The authors declare that they have no competing interests.

\section{Author details}

${ }^{1}$ Hubei Key Laboratory of Waterlogging Disaster and Agricultural Use of Wetland/Institute of Pesticides/College of Agriculture/College of Life Science/ College of Horticulture and Gardening, Yangtze University, Jingzhou 434025, Hubei, China. ${ }^{2}$ School of Environmental Sciences, University of Guelph, Guelph, ON N1G 2W1, Canada. 
Received: 8 November 2021 Accepted: 10 January 2022

Published online: 26 January 2022

\section{References}

1. Wu HX, Xu HH, Marivingt-Mounir C, Bonnemain JL, Chollet JF. Vectorizing agrochemicals: enhancing bioavailability via carrier-mediated transport. Pest Manag Sci. 2019;75:1507-16.

2. Chollet JF, Rocher F, Jousse C, Delétage-Grandon C, Bashiardes G, Bonnemain JL. Acidic derivatives of the fungicide fenpiclonil: effect of adding a methyl group to the $\mathrm{N}$-substituted chain on systemicity and fungicidal activity. Pest Manag Sci. 2005;61:377-82.

3. Fischer WN, André B, Rentsch D, Krolkiewicz S, Tegeder M, Breitkreuz K, Frommer WB. Amino acid transport in plants. Trends Plants Sci. 1998;3(5):188-95.

4. Chollet JF, Delétage C, Faucher M, Miginiac L, Bonnemain JL. Synthesis and structure-activity relationships of some pesticides with an a-amino acid function. Biochem Biophys Acta. 1997;1336:331-41.

5. Xie Y, Zhao JL, Wang CW, Yu AX, Liu N, Chen L, Lin F, Xu HH. Glycinergicfipronil uptake is mediated by an amino acid carrier system and induces the expression of amino acid transporter genes in Ricinus communis seedlings. J Agric Food Chem. 2016;64:3810-8.

6. Qin PW, Wang J, Wang H, Wen YJ, Lu ML, Li YF, Xu YS, Xu HH. Synthesis of rotenone-O-monosaccharide derivatives and their phloem mobility. J Agric Food Chem. 2014;62:4521-7.

7. Yao GK, Wen YJ, Zhao C, Xu HH. Novel amino acid ester-chlorantraniliprole conjugates: design, synthesis, phloem accumulation and bioactivity. Pest Manag Sci. 2017;73:2131-7.

8. Su JJ, Zhou Q, Zhong HY, Li YQ, Huang XQ, Xu YQ. Medium optimization for phenazine-1-carboxylic acid production by a gacA qscR double mutant of Pseudomonas sp. M18 using response surface methodology. Bioresour Technol. 2010;101:4089-95.

9. Yu LH, Huang D, Zhu X, Zhang M, Yao ZL, Wu QL, Xu ZH, Li JK. Design, synthesis, phloem mobility, and bioactivities of a series of phenazine1-carboxylic acid-amino acid conjugates. Molecules. 2018;23:2139.

10. Zhu X, Yu LH, Hsiang T, Huang D, Xu ZH, Wu QL, Du XY, Li JK. The influence of steric configuration of phenazine-1-carboxylic acid-amino acid conjugates on fungicidal activity and systemicity. Pest Manag Sci. 2019;75:3323-30.

11. Liu X, Bush DR. Expression and transcriptional regulation of amino acid transporters in plants. Amino Acids. 2006;30:113-20.

12. Foster J, Lee YH, Tegeder M. Distinct expression of members of the LHT amino acid transporter family in flowers indicates specific roles in plant reproduction. Sex Plant Reprod. 2008;21:143-52.

13. Mao GL, Yan Y, Chen Y, Wang BF, Xu FF, Zhang ZX, Lin F, Xu HH. The family of Ricinus communis monosaccharide transporters and the RCSTP1 in promoting the uptake of a glucose-fipronil conjugate. J Agric Food Chem. 2017;65:6169-78.

14. Ren ZF, Chen ZT, Luo X, Su JB, Yao GK, Xu HH, Lin F. Overexpression of AtAAP1 increased the uptake of an alanine-chlorantraniliprole conjugate in Arabidopsis thaliana. Environ Sci and Pollut Res. 2019;26:36680-7.

15. Kallarackal J, Orlich G, Schobert C, Komor E. Sucrose transport into the phloem of Ricinus communis L. seedlings as measured by the analysis of sieve-tube sap. Planta. 1989;177:327-35.

16. Prasad MSL, Raoof MA, Gayatri B, Anjani K, Lavanya C, Prasad RD, et al. Wilt disease of castor: an overview. Indian Phytopathol. 2019;72:575-85.

17. Park YJ, Han JE, Lee H, Lee JY, Ho TT, Park SY. Production of recombinant miraculin protein in carrot callus via Agrobacterium-mediated transformation. Plant Cell Tissue Organ Cult. 2021;145:615-23.

18. Van Eck J, Keen P,Tjahjadi M. Agrobacterium tumefaciens-mediated transformation of tomato. Methods Mol Biol. 2019;1864:225-34.

19. Cheng M, Fry JE, Zhou H, Hironaka CM, Duncan DR, Coner TW, Wan YC. Genetic transformation of wheat mediated by Agrobacterium tumefaciens. Plant Physiol. 1997;115:971-80.

20. Clough SJ, Bent AF. Floral dip: a simplified method for Agrobacteriummediated transformation of Arabidopsis thaliana. Plant J. 1998;6:735-43.

21. Leelavathi S, Sunnichan VG, Kumria R, Vijaykanth GP, Bhatnagar RK, Reddy VS. A simple and rapid Agrobacterium-mediated transformation protocol for cotton (Gossypium hirsutum L.): embryogenic calli as a source to generate large numbers of transgenic plants. Plant Cell Rep. 2004;22:465-70.
22. Liu Z, Park BJ, Kanno A, Kameya T. The novel use of a combination of sonication and vacuum infiltration in Agrobacterium-mediated transformation of kidney bean (Phaseolus vulgaris L.) with lea gene. Mol Breed. 2005;16:189-97.

23. Acereto-Escoffié POM, Chi-Manzanero BH, Echeverría-Echeverría S, Grijalva R, James Kay A, González-Estrada T, Castaño E, Rodríguez-Zapata LC. Agrobacterium-mediated transformation of Musa acuminata cv. "Grand Nain" scalps by vacuum infiltration. Sci Horticult. 2005;105:359-71.

24. Canche-Moo RLR, Ku-Gonzalez A, Burgeff C, Loyola-Vargas VM, Rodríguez-Zapata LC, Castaño E. Genetic transformation of Coffea canephora by vacuum infiltration. Plant Cell Tissue Org Cult. 2006;84:373-7.

25. Oliveira MLPd, Febres VJ, Costa MGC, Moore GA, Otoni WC. High-efficiency Agrobacterium-mediated transformation of citrus via sonication and vacuum infiltration. Plant Cell Rep. 2009;28:387-95.

26. Vasudevan V, Ramamoorthy S, Veda K, Markandan M. Polyamines, sonication and vacuum infiltration enhances the Agrobacterium-mediated transformation in watermelon (Citrullus lanatus Thunb.). S Afr J Bot. 2020;128:333-8.

27. Charity JA, Holland L, Donaldson SS, Grace L, Walter C. Agrobacteriummediated transformation of Pinus radiata organogenic tissue using vacuum-infiltration. Plant Cell Tissue Organ Cult. 2002;70:51-60.

28. Amoah BK, Wu H, Sparks C, Jones HD. Factors influencing Agrobacteriummediated transient expression of uidA in wheat inflorescence tissue. J Exp Bot. 2001;52:1135-42.

29. Rocher F, Chollet JF, Jousse C, Bonnemain JL. Salicylic acid, an ambimobile molecule exhibiting a high ability to accumulate in the phloem. Plant Physiol. 2006;141(4):1684-93.

30. Kiselev KV, Aleynova OA, Ogneva ZV, Suprun AR, Dubrovina AS, et al. $35 \mathrm{~S}$ promoter-driven transgenes are variably expressed in different organs of Arabidopsis thaliana and in response to abiotic stress. Mol Biol Rep. 2021;48:2235-41.

31. Zong Y, Li SM, Xi XY, Cao D, Wang Z, Wang R, et al. Comprehensive influences of overexpression of a MYB transcriptor regulating anthocyanin biosynthesis on transcriptome and metabolome of tobacco leaves. Int J Mol Sci. 2019;20:5123.

32. Yin JL, Wang LX, Zhao J, Li Y T, Huang R, Jiang XC, Zhou XK, Zhu XM, He $Y, H e Y$, Liu YQ, Zhu YX. Genome-wide characterization of the $\mathrm{C}_{2} \mathrm{H}_{2}$ zincfinger genes in Cucumis sativus and functional analyses of four CsZFPs in response to stresses. BMC Plant Biol. 2020;20:359.

33. Zhu YX, Guo J, Feng R, Jia JH, Han WH, Gong HJ. The regulatory role of silicon on carbohydrate metabolism in Cucumis sativus L. under salt stress. Plant Soil. 2016:406:231-49.

34. Chomczynski P, Sacchi N. The single-step method of RNA isolation by acid guanidinium thiocyanate-phenol-chloroform extraction: twentysomething years on. Nat Protoc. 2006;1:581-5.

35. Livak KJ, Schmittgen TD. Analysis of relative gene expression data using real-time quantitative PCR and the $2^{-\triangle \Delta C T}$ method. Methods. 2001;25:402-8.

36. Singh VK, Mangalam AK, Dwivedi S, Naik S. Primer premier: program for design of degenerate primers from a protein sequence. Biotechniques. 1998;24:318-9.

37. Kim MH, Liu W, Borjesson DL, Curry FRE, Miler LS, Cheung AL, et al. Dynamics of neutrophil infiltration during cutaneous wound healing and infection using fluorescence imaging. J Invest Dermatol. 2008;128:1812-20.

38. Sleight SC, Bartley BA, Lieviant JA, Sauro HM, et al. In-fusion BioBrick assembly and re-engineering. Nucleic Acids Res. 2010;38:2624-36.

39. Tichá I, Čatský J. Leaf architecture and net photosynthetic rate during ontogeny of primary French bean leaves. In: Marcelle R, Clijsters H, van Poucke M, editors. Biological control of photosynthesis, vol. 19. Advances in agricultural biotechnology. Berlin: Springer; 1986. p. 209-17.

40. Musiychuk K, Stephenson N, Hong B, Farrance CE, Orozovic G, Brodelius $M$, et al. A launch vector for the prodtiucon of vaccine antigens in plants. Influenza Other Respir Viruses. 2007;1:19-25.

41. Shamloul M, Trusa J, Mett V, Yusibov V. Optimization and utilization of Agrobacterium-mediated transient protein production in Nicotiana. J Vis Exp. 2014;86:e51204.

42. Gleba Y, KlimyukV, Marillonnet S. Magnifection-a new platform for expressing recombinant vaccines in plants. Vaccine. 2005;23:2042-8. 
43. Kapila J, DeRycke R, Van Montagu M, Angenon G. An Agrobacteriummediated transient gene expression system for intact leaves. Plant Sci. 1997;122:101-8.

44. Yang YN, Li RG, Qi M. In vivo analysis of plant promoters and transcription factors by agroinfiltration of tobacco leaves. Plant J. 2000;22:543-51.

45. Bechtold N, Pelletier G. In planta Agrobacterium-mediated transformation of adult Arabidopsis thaliana plants by vacuum infiltration. Methods Mol Biol. 1998;82:259-66.

46. Simmons CW, VanderGheynst JS, Upadhyaya SK. A model of agrobacterium tumefaciens vacuum infiltration into harvested leaf tissue and subsequent in planta transgene transient expression. Biotechnol Bioeng. 2009;102:965-70

47. Marillonnet S, Thoeringer C, Kandzia R, Klimyuk V, Gleba Y. Systemic Agrobacterium tumefaciens-mediated transfection of viral replicons for efficient transient expression in plants. Nat Biotechnol. 2005;23:718-23.

48. Foster JJ. Characterization of amino acid transporter function in Arabidopsis thaliana. Washington, DC: Washington State University; 2008.

49. Jiang XY, Xie Y, Ren ZF, Ganeteg U, Lin F, Zhao C, et al. Design of a new glutamine-fipronil conjugate with a-amino acid function and its uptake by A. thaliana lysine histidine transporter 1 (AtLHT1). J Agric Food Chem. 2018;66:7597-605.

\section{Publisher's Note}

Springer Nature remains neutral with regard to jurisdictional claims in published maps and institutional affiliations.

- fast, convenient online submission

- thorough peer review by experienced researchers in your field

- rapid publication on acceptance

- support for research data, including large and complex data types

- gold Open Access which fosters wider collaboration and increased citations

- maximum visibility for your research: over 100M website views per year

At BMC, research is always in progress.

Learn more biomedcentral.com/submissions 